\title{
Female Students' Dilemma of Wearing Islamic Headscarf
}

\author{
R Rusmawati ${ }^{1}$, S Herminingrum ${ }^{2}$, \\ 1,2 Universitas Brawijaya, Malang, Jawa Timur, Indonesia \\ $\left\{1\right.$ roosi_rusmawati@ub.ac.id, ${ }^{2}$ hermien_18@ub.ac.id\}
}

\begin{abstract}
Young immigrants in France should attend the school as they are part of citizens of France. However, the female students who wear Islamic headscarf - that are distinctive from their fellows - can potentially cause a problem in relation to the government's effort in realizing national integrity and enforcing secular principles. Thus, this study uses Van Kaam's Phenomenological Method in order to reveal the purpose and the process of compromising towards the ratification of the French government law dated March 15, 2004. The data was collected through ten-participant observation and in-depth interviews for four months in 2003 with high school Muslim female students of Maghrebi descent who wear Islamic headscarf in the Ile-de-France province. The strong cultural education in their family put them into a dilemma between wearing the Islamic headscarf and taking it off. However, their compromise arises from their hope for a better future through school.
\end{abstract}

Keywords: Laïcité, Islamic Headscarf, Law Dated March 15-2004, Maghrebi Immigrant.

\section{INTRODUCTION}

France is a laïcité country settled by residents of various origins, starting from the French until more recent immigrants coming from the number of countries throughout the world, both European countries, and countries in other continents. The majority of immigrants in France have come from its ex-colonies, especially Maghrebi countries [1]. Maghrebi countries are those located in Western Africa, bordered in the north by the Mediterranean Sea, the south by the Sahara Desert, the west by The North Atlantic Ocean, and the east by Libya. Such Maghrebi countries are referred to as Algeria, Tunisia, and Morocco [2].

The immigrants entering the destination countries also bring their own cultures, so do the immigrants from Maghrebi countries with an Arab Islamic culture who entered the country of France. The Arabic language used in the Maghrebi countries began since the conquest of countries on the African continent by the Bani Ummayah government who spread Islam. This government was in power in the African continent for 12 centuries starting from the 7th century to the 19th century. Indirectly, the spread of Islam has influenced the spread Arabic language. In addition to language and religion, holiday celebrations can also reflect the culture of a country. The people of the Maghrebi countries always celebrate their big day along with the Islamic holidays [1] 
France's Muslim population during the 1980s comprised about four million inhabitants. At that time, this represented the largest Muslim community in Europe. The acculturation process of people of Maghrebi origin to the laïcité culture does not run smoothly. One of the problems is when their kids, especially the females, are about to attend school, they would wear a different outfit from those of other girls, that is the Islamic headscarf. That kind of outfit will surely draw attention, both from their friends and the teachers. Some teachers feel disturbed by what their wear, but others have no problems with it. The different opinions among the teachers is not confined to one school. There are many schools dealing with the same problem. This condition disorganized the principal in relation to whether or not the school should meet the teacher's requirement of not agreeing with Islamic headscarf, by issuing a new regulation on wearing of the school uniform. The Ministry of Education of France therefore proposed the problem to the government, and on 27 November 1989 the government introduced a new regulation to give autonomy to the principals. Surprisingly, the government decree did not overcome the problem, since each principal makes a different decision. To overcome this problem, Luc Ferry, The Minister of Youth Affairs, National Education and Research France in 2003 submitted a draft of law banning the use of religious symbols, including the headscarf, in the school and the government environment validated this draft law into a Law on Laïcité 2004 Law [1]

The introduction of the Laïcité 2004 law or so-called Loi du 15 March 2004 at the beginning of the 2004/2005 school year, the government of France, Francois Fillon who is The Minister of National Education of France in 2004 said that there have been no issues or occasion of conflict. While there are female students who wear and take off their Islamic headscarves in front of the school yard, the government wishes that this phenomenon will not be adopted by many students for families [3]. In fact, after about 10 years of implementation of the laïcité law, there are many high school Muslim female students, especially those coming from Islamic culture countries, including the Maghrebians who wear Islamic headscarf, showing their identity/religion in public spaces and who take off their Islamic headscarf when at school. Some of the researchers have reported that the number of them is getting higher.

Getting along with that issue, this research was conducted. The research was undertaken in Île-de-France Province, Paris. Like many other capital cities in other countries, Paris is the destination city for many immigrants seeking to earn money. In addition, the first Great Mosque, La Grande Mosquée de Paris, the symbol of French government's recognition of the Islamic culture and religion, is located in Paris, at Place de Puits de l'Ermite. In order to study this phenomenon, this study uses Bourdieu's $(1980,1994,2014)$ social theory [4], because this theory can reveal the process of compromise and the purpose of why respondents put on and take off the headscarf in school. The study was conducted within a qualitative paradigm and reviewed in relation to the meaning for the action of taking off and putting on Islamic headscarf, as practiced by some high school Muslim female students, in particular the immigrants of Maghrebi origin with an Arab-Islamic culture who wear Islamic headscarf at school.

\subsection{Research Method}

The study further uses phenomenology strategy [5]. The data were analyzed using Van Kaam's Phenomenology Data Analysis method was collected through in-depth interviews with the ten respondents, non-participant observations and participant observations of the respondents' activities, with data logging through Field Note [6]. Moreover, Kuswarno (2009) 
stated that in phenomenology research, the selection of respondents was based on those who experienced and felt for themselves the phenomenon that are being studied. Therefore, the High School Muslim female students from Maghrebi origin who take off their Islamic headscarf when entering the gate of the school and putting it on again when they left the school to go home are considered as the respondents. Data collection started by a single respondent who was willing to participate in this research and further helped the researcher contacting other respondents. The number of respondents was not determined by the numbers but based on maximum information acquisition Besides Creswell in his book entitled Qualitative Inquiry and Research Design said that: "Data collection activities can be carried out on more than 10 (ten) respondents" [5] then with 10 respondents, this research has received maximum information.

\subsection{Results and Discussions}

Based on Bourdieu's proposal [7], Habitus is not formed all of sudden but goes through a long process in the form of individual experiences when interacting with the social world. Furthermore, his concept was supported by Wempi (2012) and Bédard (2003), they confirmed Habitus was built through the education process; Bourdieu divides it into three parts, these being family education, social education, and education at school. From those three steps of process, there are a number of dispositions, intervention schemes or perceptions that individual have accepted through social etiquette. From the various experiences and events they have been through, every individual gradually unites a number of ways of thinking, feeling and behaving that become obvious in the long term.

Dispositions, interventions schemes or perceptions in values, moral, customs, religious culture, lateral thinking and lateral action received by the respondents are; Firstly, through the family environment, values, morals, and customs that are internalized from the original culture of great-grandparents or their parents, namely the Arab-Islamic culture. Even though they might have been born and brought up in France, the values, morals, and custom internalized by their parents and family, are those of the Arab-Islamic culture, since they inherit the belief from their ancestors, even though there maybe one or two of their relatives or parents who practice and do not practice religious rituals. In addition to religion, the language they use to communicate every day is the Arabic language and their closeness to their country of origin is proven by all the respondents who had visited the country of their grandparents, that is Maghrebi. For example, from the results of interviews with Chanez (pseudonym), the one and only respondent who has been married in Algeria, the country of origin of her parents. They returned to Algeria because Chanez's parents wanted to marry off their children with a traditional wedding ceremony and celebrate the wedding party together with all the family, thenceforth, return to France. From this example, it is seen that the Chanez's family still strongly holds the customs of their native country.

Secondly, through the home environment; the internalized culture is still remained, namely the Arab-Islamic culture. From the data, we know that the respondents live in a low-cost apartment called HLM (Habitation à Loyers Modérés) or a residence with low costs located in a suburb of France. They live in particular regions commonly categorized into ZUS (Zona $d^{\prime}$ Urbaines Sensibles) and form a group according to their country of origin. The government maps out several regions in France into several zones, among other are ZUS which means sensitive urban area. It is called sensitive since it is an area of many criminal acts. Even though they were born in France, the environment in which they live now supports their attitude to keep holding their original culture. Referring to this kind of phenomenon, several 
experts of social science refer to them as "living in the ghetto". The similarity is in relation to the applicable laws and rules in the home environment which tends to be specific, and different from the laws or rules of the country where "ghetto" is located. The real "ghetto" shows that the applicable laws or rules originally come from the Jewish, while even the "ghetto" is in Germany. The rules or laws practiced at HLM are Arab-Islamic laws or rules, even though the HLM is in France. However, other sociology experts in France do not agree with that perception [8].

Thirdly, through the wider environment, that is when they attend school. Almost all respondents come from a pre-prosperous family whose economic status is below the standard of prosperous family. In this context, when the time to enter school comes, they choose to attend a public school since it is free. At public schools, the children of immigrant descent start learning French's laïcité culture. This is known from the interview results that most of them learnt the term laïcité from school. Laïcité is one of five principles of the public school education system in France, that is: free (La Gratuité), secular (La Laïcité), obligatory (L'Obligation Scolaire), neutral (La Neutralité), and freedom of establishing education (La Liberté d'Enseignement) [9]

Upon returning to their homes from school at the end of the week, the respondents commonly learn to recite Al-Qur'an and Islam as well as its culture in Mosques or Islamic schools in their neighborhood. They also attend Islamic learning forums for women, even though not on a regular basis. Through their teachers at the informal schools and the Islamic learning forum, moral values and the Arab-Islamic culture are strengthened again. Islam development throughout the world is getting higher in recent times especially since 9/11 attack, the series of four suicide attacks have been set against several targets in New York City and Washington, D.C. on September 11, 2001, including in France. In Paris, it is easy to find spaces in an Islamic school, the place for children to learn to recite Al-Quran. In addition, women in the Muslim community often hold Islamic learning forums. This phenomenon started developing since the government verified the Law dated March 15, 2004 [1].

There are many building or spaces that are not resembled to that of a general mosque to be functioned as mosque. Those are not only functioned as the place to practice religious ritual such as praying but also providing space to study Islam and its culture. This development of Islam influences the younger Muslim generations to become motivated to re-learn Islam, its related history, and at the time, practice Islamic cultural rituals. This was observed also in relation to this study's participants. Commonly, the respondents choose to wear Islamic headscarf after they learn about Islam and its culture, not because of the influence of their parents or another family. This was also known from the interview results.

Even though they are descendants of the third or fourth immigrants and they spend most of their lives in France, the habitus they received is indigenous culture, especially in the first and second stages of the education process. However, only in the third stage of the education process did they get the native French culture of laïcité which is when they started entering official school. Even when they have entered official school, upon returning from school, they re-learn Islam and culture in the mosques closest to their neighborhood. This shows that they have never been separated from their original culture both in the first, second, and third stages of the education process.

Bourdieu describes society as an arena (champ) with intertwined arrangements. Agents, either actors or institutions, do not move in empty space but in a champ. Champ or the arena of struggle is a real social situation organized and controlled by objective social relations. Champ is a network of relationships between objective positions within it. The relationship is separated from the consciousness and will of the individual [10]. 
The term champ in this study refers to educational arena. There are three ways to analyze champ; firstly, by looking at how the champ and government relationships exist; secondly, by looking at how the positions between agents competing in the arena and it is described through champ and agent's analysis; thirdly, by looking at how the habitus agent operates [8]. The first analysis: in the champ of education in France, the government is the champ of power because education in France is centralized. It is the government that controls the champ of educational through the Minister of National Education, Teaching of Universities and Research (Ministère de l'Éducation Nationale, de l'Enseignement Supérieur et de la Recherche) [9]. Educational institutions, in France, are one of three important areas (the other two being health-care institutions and civil code) where the French laïcité principle must be upheld. From history, education the younger generation of French was originally the responsibility of the church. Since the French Revolution, it has gradually shifted to become the responsibility of the government. The figures of the France Enlightenment Century teach people to no longer believe in religion, including in educating the younger generation. The government's way of doing this is to abolish religious subjects and replace them with subjects of character and citizenship (instruction morale et civique) and forbid religion to be taught in schools [11].

In the second analysis, maps of objective structures are illustrated by champ analysis of the reality of a Muslim girl students group wearing Islamic headscarf. They are in a subordinate or dominated position in the educational champ whose legitimacy principle is based on the ownership of political capital and symbolic capital. French education is centralized. The hierarchy in government, which is a political capital, has the same structure as the hierarchy in education. On the other hand, laïcité is a very strong symbolic capital and in this study, it is seen in the school area.

In the third analysis, Habitus agents, are high school Muslim girl students who take their Islamic headscarf off when entering the school area and put it on again when leaving school. As mentioned earlier, the first internalized habitus of respondents is Arab-Islamic in nature. Furthermore, the second internalized habitus of the respondents is Arab-Islamic and laïcité because at school they undergo the internalization of laïcité principles.

Based on the results of the champ analysis above, it can be concluded that the interaction of respondents in the educational arena is not a burden to get a position, but to get bigger capital. The educational champ is ruled by the government as the supreme ruler of a country. Therefore, the position of the government in the educational champ is irreplaceable. While in the educational champ, respondents are in a dominated position. They have no bargaining status in term of not having enough capital to be able to fight in the educational champ. Moreover, in addition to public schools, France also has private schools where the Law dated March 15, 2004, is not enacted. Thus, the government assumes that if students in public schools cannot comply with the public law, then they can move to private schools.

Champ which is analogized as a battle champ or game champ, raises the understanding that in the arena there are players, rules, goals, and results. Competitions between players that occur in the champ raise the strategies used to achieve goals. Strategy acts as a way for players to improve and/or maintain their position in the game champ. Champ is also a battleground to fight for a variety of capital items, such as economic, social, cultural and symbolic capital. In principle, the proportion and amount of capital of an agent can provide an opportunity for movement of agency positions within the community. However, the facts in the field indicate that not all agents have all four types of capital at the same time. In this study, the first habitus of respondents is Arab-Islamic in nature, while the second habitus is Arab-Islamic in nature by wearing Islamic headscarf in daily activities and the principle of Laïcité. Through the lessons they learned at an Islamic school, respondents said that the wearing of Islamic headscarf by 
adult Muslim women is mandatory. Therefore, they do not want to take it off in daily activities, including when they go to school. However, they have to keep going to school to get an education.

In order to obtain higher capital, in this case, it is the culture of institutionalization in the form of a baccalauréat diploma, by having this diploma, the respondents can continue their education to higher level by taking their Islamic headscarf off in front of the gate before entering the school area and put it on again when leaving school. Two respondents confirmed this.

Ihsen (17 years old): "Je suis obligée d'enlever mon voile en entrant dans le lycée et je sais bien que c'est à cause de la loi du 15 mars 2004», elle ajoute: "parce que la loi l'a décidée. Pour garder mon voile, je ne veux me rendre en sortant du lycée, parce que je sais en effet ce que le gouvernement souhaite ; pour que je ne puisse pas étudier»

"I am required to take off my Islamic headscarf when entering the school area and I know for sure, this is because of Law dated March 15, 2004», she gives an explanation: «since law has established it. In order to defend her Islamic headscarf, "I do not want to be lost by leaving school, because I actually know what the government wants; they want me to not be able to attend school."

Chanez (18 years old) also said something similar:

"Je partage l'avis de Ihsen. Les Français ne veulent pas que nous soyons aussi intelligentes qu'eux. Je suis obligée d'enlever le voile en entrant dans le lycée, car la loi française l'impose, le voile est malheureux dans les lycées publics. Nous nous sommes renseignées à Internet sure Cette loi»»

"I agree with Ihsan's opinion. The French do not like us being as smart as them. I am obliged to take off my Islamic headscarf when entering school since the regulation forced it; Islamic headscarf is really pitiful at public schools. We find out via the internet (about the Law dated March 15, 2004)"

Through the statements of two respondents above, it can be concluded that they prioritize education. To get an education they have to go to public school because the tuition is free. Almost all respondents answered that their parents did not have money to send them to private schools. In addition to the ten respondents, there were eight people who will continue their education to higher level. Through this explanation, it is increasingly apparent that the practice of taking off and putting on the Islamic headscarf is their strategy to continue to attend school and achieve a better future.

\section{CONCLUSIONS}

The result of the study confirms that, the praxis of taking off and putting on the Islamic headscarf is a form of compromise on Law dated March 15, 2004, a law that prohibits the use of religious symbols in public school area from elementary school to high school level. This compromise aims to make them stay in school and get a diploma of baccalaureate. The absolute prerequisite for continuing education at universities, where they can study the subject they want and as much as they want, without having to take their Islamic headscarf off because Law March 15, 2004 is not enforced at university colleges. It is a strategic conformity of female students of Maghrebi immigrant to achieve a better future in their new land. 


\section{REFERENCES}

[1] Rusmawati, R. 2009. Undang-Undang Laïcité 2004 (sebuah analisis terhadap disyahkannya undang-undang pelarangan pemakaian simbol-simbol keagamaan di sekolah-sekolah negeri di Prancis). Laporan Penelitian dalam Jurnal Kajian Wilayah Eropa Vol.5 No.1 tahun 2009. 2009.

[2] Encyclopedie, Le Monde d'Aujourd'hui, Larousse-Bordes,.Paris. 1997.

[3] Blimann, Sophie (2011) Laïcité dans Les Etablissements Scolaires: La Loi de 2004 a clarifié la Situation Available at: http://www.letudiant.fr/educpros/actualite/laicite-dansles-etablissements-scolaires-la-loi-de-2004-a-clarifie-la-situation.html. 2011.

[4] Fashri, Fauzi. Penyingkapan Kuasa Simbol, Apropnasi, Reflektivi Pemikiran Pierre Bourdieu. Bantul Yogyakarta: Juxtapose. 2007.

[5] Creswell, John W. Research Design, Qualitative, Quantitative and Mixed Approach. Translator: Achmad Fawaid. Yogyakarta: PUSTAKA PELAJAR. 2012.

[6] Kuswarno, Engkus. (2009) Fenomenologi: Metode Penelitian Komunikasi. Bandung: Widya Padjajaran. 2009.

[7] Mucchielli, Laurent. "Pierre Bourdieu et le changement social." Alternatives économiques 175. page: 64-67. 1999.

[8] Marchal, Hervé, and Jean-Marc Stébé. Les grands ensembles: nouveaux ghettos français, Métropolitiques. Available at: http://www.metropolitiques.eu/Les-grands-ensemblesnouveaux.html. 2010.

[9] Rusmawati, R. Internalisasi Disposisi Siswa Perempuan Imigran Asal Negeri Maghribi Terhadap Undang-Undang 15 Maret 2004 (Studi Voile Islamique di SMA Negeri di Ilede-France Prancis). 2017.

[10] Ritzer, George, Douglas J. Goodman Teori Sosiologi Modern. Jakarta: Kencana Prenada Media Group. 2011.

[11] Baubérot, Jean. Que sais-je? Histoire de la Lä̈cité en France. Paris: Presses Université de France. 2010 